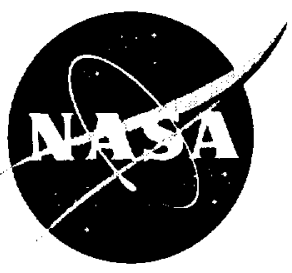

\title{
Strain Gage Loads Calibration Testing of the Active Aeroelastic Wing F/A-18 Aircraft
}

William A. Lokos, Candida D. Olney, Tony Chen, and Natalie D. Crawford NASA Dryden Flight Research Center

Edwards, California

Rick Stauf

Spiral Technology Inc.

Lancaster, California

Eric Y. Reichenbach

The Boeing Company

St. Louis, Missouri 


\section{The NASA STI Program Office...in Profile}

Since its founding, NASA has been dedicated to the advancement of aeronautics and space science. The NASA Scientific and Technical Information (STI) Program Office plays a key part in helping NASA maintain this important role.

The NASA STI Program Office is operated by Langley Research Center, the lead center for NASA's scientific and technical information. The NASA STI Program Office provides access to the NASA STI Database, the largest collection of aeronautical and space science STI in the world. The Program Office is also NASA's institutional mechanism for disseminating the results of its research and development activities. These results are published by NASA in the NASA STI Report Series, which includes the following report types:

- TECHNICAL PUBLICATION. Reports of completed research or a major significant phase of research that present the results of NASA programs and include extensive data or theoretical analysis. Includes compilations of significant scientific and technical data and information deemed to be of continuing reference value. NASA's counterpart of peer-reviewed formal professional papers but has less stringent limitations on manuscript length and extent of graphic presentations.

- TECHNICAL MEMORANDUM. Scientific and technical findings that are preliminary or of specialized interest, e.g., quick release reports, working papers, and bibliographies that contain minimal annotation. Does not contain extensive analysis.

- CONTRACTOR REPORT. Scientific and technical findings by NASA-sponsored contractors and grantees.
- CONFERENCE PUBLICATION. Collected papers from scientific and technical conferences, symposia, seminars, or other meetings sponsored or cosponsored by NASA.

- SPECIAL PUBLICATION. Scientific, technical, or historical information from NASA programs, projects, and mission, often concerned with subjects having substantial public interest.

- TECHNICAL TRANSLATION. Englishlanguage translations of foreign scientific and technical material pertinent to NASA's mission.

Specialized services that complement the STI Program Office's diverse offerings include creating custom thesauri, building customized databases, organizing and publishing research results...even providing videos.

For more information about the NASA STI Program Office, see the following:

- Access the NASA STI Program Home Page at http://www.sti.nasa.gov

- E-mail your question via the Internet to help@sti.nasa.gov

- Fax your question to the NASA Access Help Desk at (301) 621-0134

- Telephone the NASA Access Help Desk at (301) 621-0390

- Write to:

NASA Access Help Desk

NASA Center for AeroSpace Information 7121 Standard Drive

Hanover, MD 21076-1320 


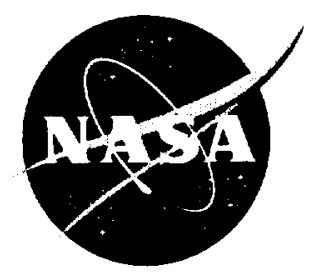

\section{Strain Gage Loads Calibration Testing of the Active Aeroelastic Wing F/A-18 Aircraft}

William A. Lokos, Candida D. Olney, Tony Chen, and Natalie D. Crawford NASA Dryden Flight Research Center

Edwards, California

Rick Stauf

Spiral Technology Inc.

Lancaster, California

Eric Y. Reichenbach

The Boeing Company

St. Louis, Missouri

National Aeronautics and

Space Administration

Dryden Flight Research Center

Edwards, California 93523-0273

May 2002 


\section{NOTICE}

Use of trade names or names of manufacturers in this document does not constitute an official endorsement of such products or manufacturers, either expressed or implied, by the National Aeronautics and Space Administration.

Available from the following:

NASA Center for AeroSpace Information (CASI)

7121 Standard Drive

Hanover, MD 21076-1320

(301) 621-0390
National Technical Information Service (NTIS) 5285 Port Royal Road Springfield, VA 22161-2171 (703) $487-4650$ 


\title{
STRAIN-GAGE LOADS CALIBRATION TESTING OF THE ACTIVE AEROELASTIC WING F/A-18 AIRPLANE
}

\author{
William A. Lokos, ${ }^{*}$ Candida D. Olney, ${ }^{\dagger}$ Tony Chen,${ }^{\ddagger}$ and Natalie D. Crawford ${ }^{\S}$ \\ NASA Dryden Flight Research Center \\ Edwards, California \\ Rick Stauf \\ Spiral Technology Inc. \\ Lancaster, California \\ Eric Y. Reichenbach ${ }^{* *}$ \\ The Boeing Company \\ St. Louis, Missouri
}

\section{$\underline{\text { Abstract }}$}

This report describes strain-gage calibration loading through the application of known loads of the Active Aeroelastic Wing F/A-18 airplane. The primary goal of this test is to produce a database suitable for deriving load equations for left and right wing root and fold shear; bending moment; torque; and all eight wing control-surface hinge moments. A secondary goal is to produce a database of wing deflections measured by string potentiometers and the onboard flight deflection measurement system. Another goal is to produce strain-gage data through both the laboratory data acquisition system and the onboard aircraft data system as a check of the aircraft system. Thirty-two hydraulic jacks have applied loads through whiffletrees to 104 tension-compression load pads bonded to the lower wing surfaces. The load pads covered approximately 60 percent of the lower wing surface. A series of 72 load cases has been performed, including single-point, double-point, and distributed load cases. Applied loads have reached 70 percent of the flight limit load. Maximum wingtip deflection has reached nearly 16 in.

\footnotetext{
*Aerospace Engineer; Member.

${ }^{\dagger}$ Aerospace Engineer.

${ }_{\text {Aerospace Engineer }}$

$\S_{\text {Aerospace Engineer; Member }}$

Structural Flight Test Engineer; Member.

** Aerospace Engineer; Member
}

Copyright (C) 2002 by the American Institute of Aeronautics and Astronautics. Inc. No copyright is asserted in the United States under Title 17, U.S. Code. The U.S. Government has a royalty-free license to exercise all rights under the copyright claimed herein for Governmental purposes. All other rights are reserved by the copyright owner
Test techniques and lessons learned are discussed, and output data are presented.

\section{Nomenclature}

$\begin{array}{ll}\text { AAW } & \text { Active Aeroelastic Wing } \\ B L & \text { butt line, in. } \\ \text { DACS } & \text { data acquisition and control system } \\ \text { FDMS } & \text { flight deflection measurement system } \\ \text { FS } & \text { fuselage station, in. } \\ & \text { Background }\end{array}$

For more than a decade, wing torsional flexibility has been proposed to aeroelastically enhance the roll maneuverability of high-performance aircraft. ${ }^{1}$ Although aeroelastic control behavior related to aileron reversal has always been avoided, even if it meant additional structural weight; when the behavior is incorporated as a preprogrammed control mode, some significant benefits can be reaped. When the mode is designed into a new airframe, reduced weight, increased maneuverability, and other advantages can be exploited. $^{2}$

The preproduction version of the F/A-18 aircraft was found to have the potential for aileron reversal within its performance envelope. Production F/A-18 aircraft therefore were built with stiffer wings to preclude this tendency and increase roll performance through conventional wing control-surface use. The NASA Active Aeroelastic Wing (AAW) F/A-18 airplane has been structurally modified to support aileron reversal research. ${ }^{3}$ The cover panels on the aft wing box have been replaced with more flexible panels to replicate the 
decreased stiffness of the original preproduction F/A-18 aircraft. Reference 4 describes the torsional stiffness testing of the modified wings.

Real-time-measured structural loads are required for research and safety-of-flight purposes. An extensive array of strain gages has been installed on wing structural members to measure these loads. An extensive buildup program was required to prepare the airplane and the test hardware and procedures for this testing.

\section{Test Objectives}

The primary objective of this test is to safely obtain calibration data from the strain-gage instrumentation installed on the AAW airplane through the application of single-point, multiple-point, and distributed loads. ${ }^{5}$ The database obtained consists of the measured load input and the strain-gage bridge outputs. These data were then used to develop strain-gage loads equations. These load equations are for shear, bending moment, and torque loads at the left and right wing root and fold and for all wing control-surface hinge moments. Figure I shows load measurement stations.

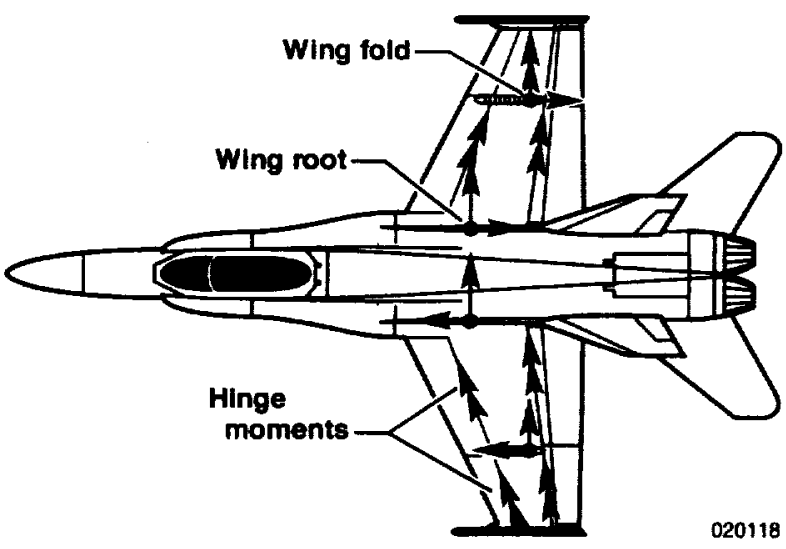

Figure 1. Flight load measurement stations.

A secondary objective is to obtain simultaneous measured data from the electro-optical flight deflection measurement system (FDMS) ${ }^{6}$ and the ground-test deflection potentiometers for measurement system comparisons. Another objective is to obtain strain-gage data through both the aircraft pulse code modulation data system and the NASA Dryden Flight Research Center (Edwards, California) Flight Loads Laboratory data acquisition and control system $(\mathrm{DACS})^{7}$ for comparative signal-to-noise ratio and error analyses.

\section{Test Description}

The following sections describe how the testing was conducted. Description of the AAW airplane configuration, restraint hardware, loading hardware, and instrumentation are included.

\section{Aiplane Configuration}

All testing was performed at the NASA Dryden Flight Loads Laboratory. ${ }^{7}$ The AAW airplane, shown ready for test in figure 2, was configured with all structural panels and control surfaces in place. Several small instrumentation access panels were removed. Dummy actuators were substituted to hold the aft wing control surfaces in place during testing. Torque shaft connections were locked in the leading-edge flap drive system to hold the leading-edge control surfaces in place. Control surfaces were rigged in the faired positions. The airplane was defueled, leaving only traces of JP-5 fuel. The arresting hook, wingtip launcher rails, main landing gear doors, and main gear were removed and dummy trunnions installed. The wing skin was premarked with the load pad outlines using a theodolite system. String potentiometer attachment tabs were preinstalled.

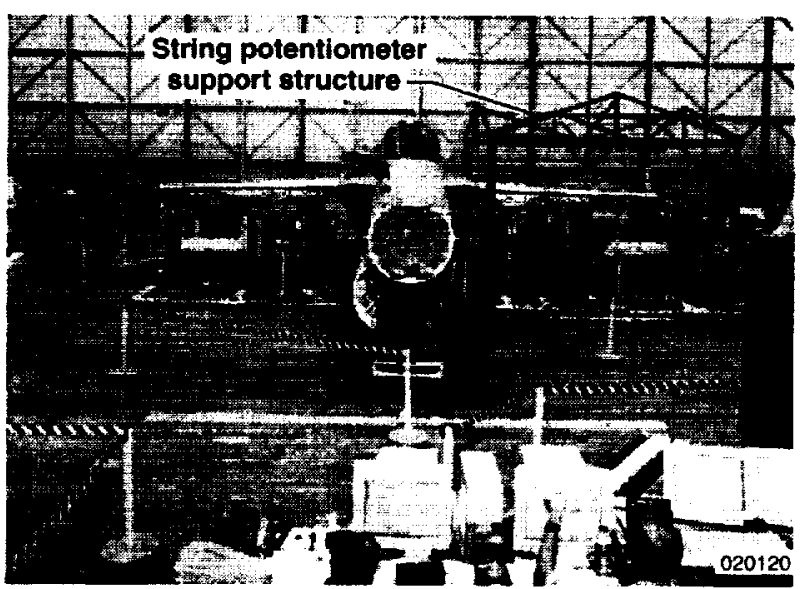

Figure 2. AAW test setup.

An attempt was made to include a protective layer of fiberglass cloth (for pad removal) bonded to the lower wing surface. Early in the schedule for aircraft preparation, however, this layer was discovered to be debonding; possibly because of fuel contamination. This fiberglass layer was removed before testing.

\section{Restraint Hardware}

The airframe was restrained at the main landing gear attachment points, the arresting hook pivot, and the nose 
gear. The dummy trunnions were attached to a restraint fixture (fig. 3). Although most other test hardware was designed for a factor of safety of $\mathbf{3 . 0}$ on ultimate, the main gear restraint fixture was designed for a factor of 5.0. This larger factor was selected because of the likely' catastrophic nature of failure of this fixture. Weight and size were not a consideration. Additionally, at the time this design was begun, the anticipated maximum net test loads were preliminary and conservative.

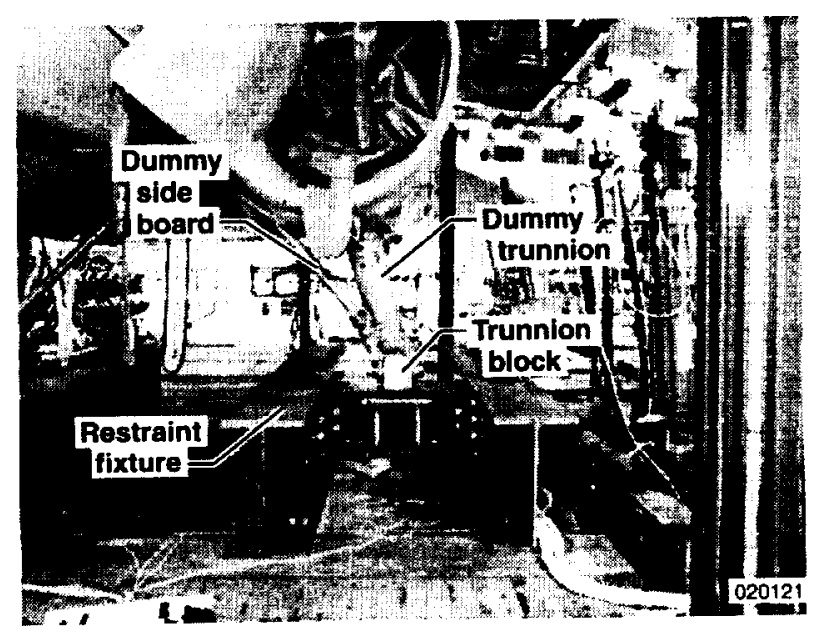

Figure 3. Main gear restraint (viewed looking aft).

The main gear fixture loads were reacted into two fioor tracks at multiple distributed points that kept the floor track loads less than their working limits. The main landing gear fuselage attachment structures, which were designed for compressive landing loads, were analyzed by the aircraft manufacturer and cleared for the large tension loads planned. The arresting hook was removed and replaced with a support structure (fig. 4). These fixtures, each resisting translation in all three

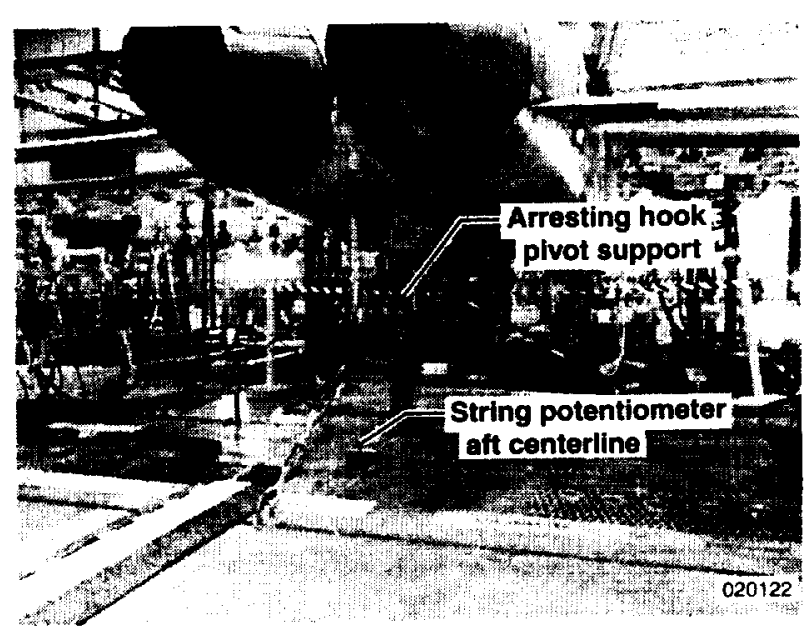

Figure 4. Arresting hook pivot restraint. axes, prevented pitching of the airplane. The nose gear was secured with loose chains for additional safety. The forward fuselage was allowed the "float" on the pressurized nose gear to avoid introducing unnecessary bending moment into the fuselage.

\section{Loading Hardware}

The following subsections discuss the loading hardware used for the test. Design considerations, load pads, whiffletrees, clevises and load cells, jack bases and contoured pins, and floor beams are described.

\section{Design Considerations}

The loading hardware (fig. 5) was designed for a factor of safety of 3.0 on ultimate except as noted. This design criterion for loading fixtures is standard practice in the Flight Loads Laboratory. Additionally, each load column was analyzed for column buckling at its maximum load and stroke.

\section{Load Pads}

The development of the load pads required a long lead time. The load zone distribution (fig. 6) provides for load pad coverage of approximately 60 percent of the lower wing surfaces. Average load pad pressure did not exceed $15 \mathrm{lbf} / \mathrm{in}^{2}$, and peak local pressure did not exceed $25 \mathrm{lbf} / \mathrm{in}^{2}$. The load pads are designed to be bonded to the wing skin and to distribute both tension and compression loads. The backing plates are 0.5-in.-thick 2024 T351 aluminum alloy. Steel could have been used, but the lighter weight of the aluminum was a benefit during installation. The 1.5-in.-thick elastomeric layer is a carefully selected neoprene rubber material. The rubber and the bonding agent (military specification polysulfide fuel tank sealant) were selected and characterized through a series of tests described in reference 8 .

Candidate load pad materials were tested for ultimate tensile strength, compressive stiffness, creep strength, and low-cycle fatigue strength. The rubber layer tensile strength achieved a factor of safety slightly more than 2.0 on ultimate. This factor of safety was considered adequate because it was determined through testing. Other criteria considered were repeatable bond quality, fuel resistance, and removability. During this test series, techniques were developed that were later used in load pad assembly and installation of all 104 load pads on the airplane. Figure 7 shows the load pads installed on the left wing.

3 


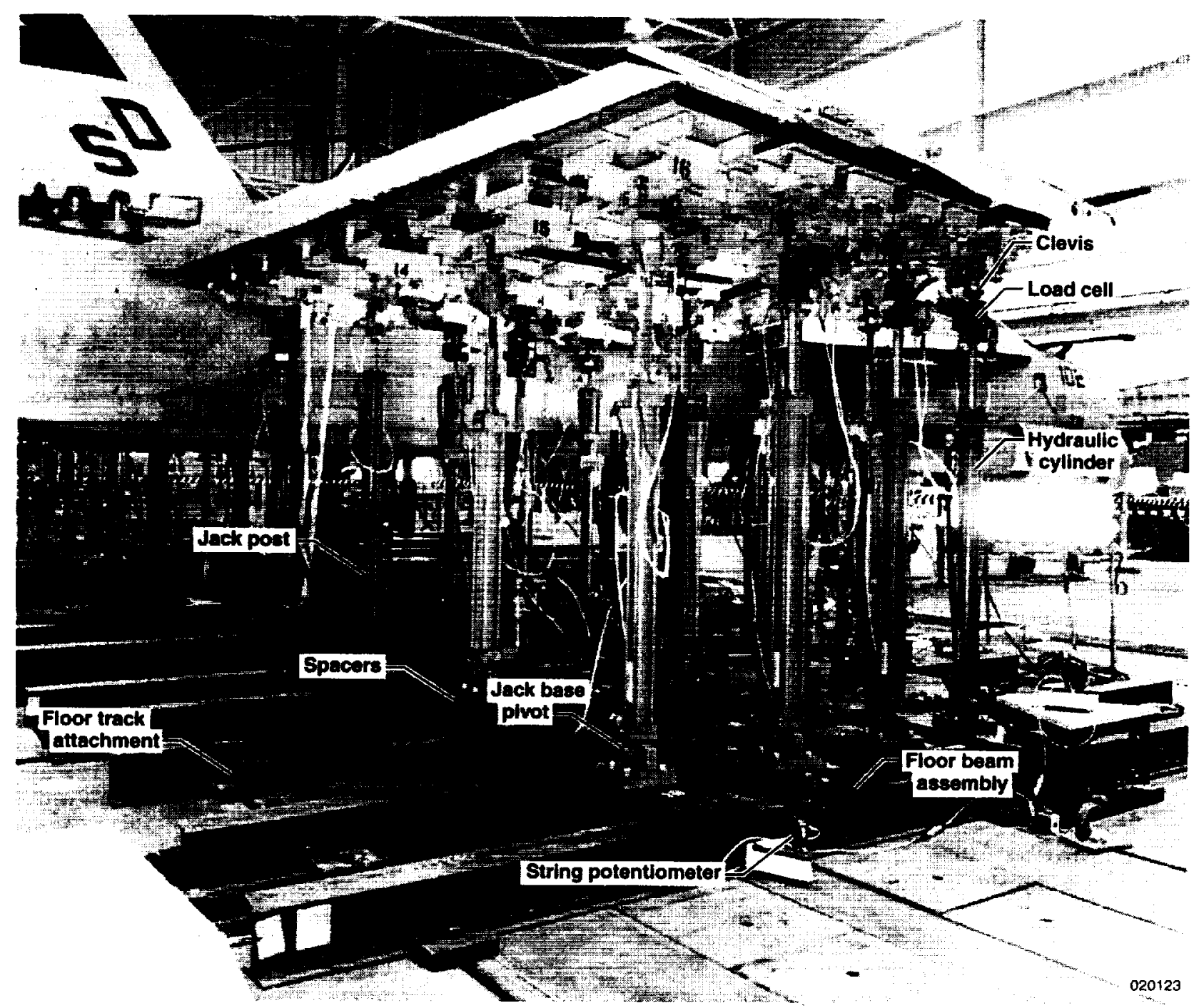

Figure 5. Right wingtip with loading hardware (viewed looking inboard and forward).

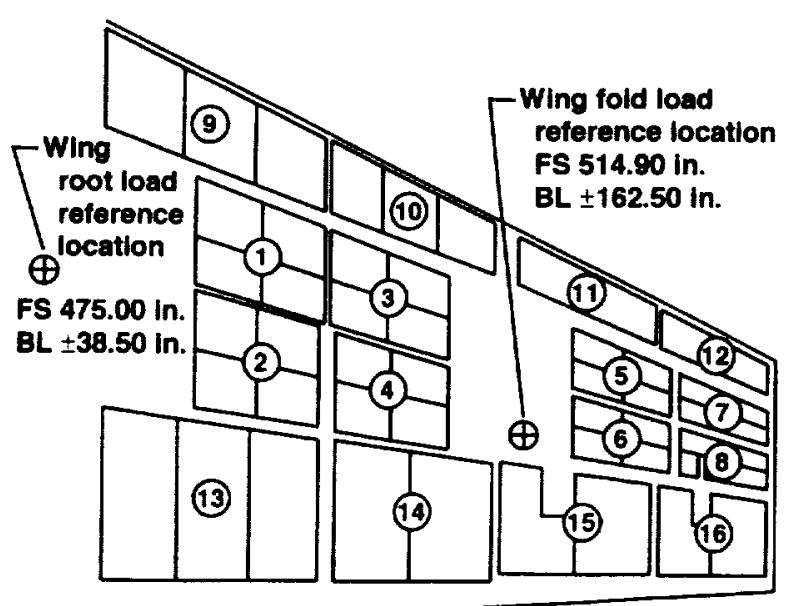

020124

Figure 6. AAW load zone distribution (viewed looking up at the left wing).

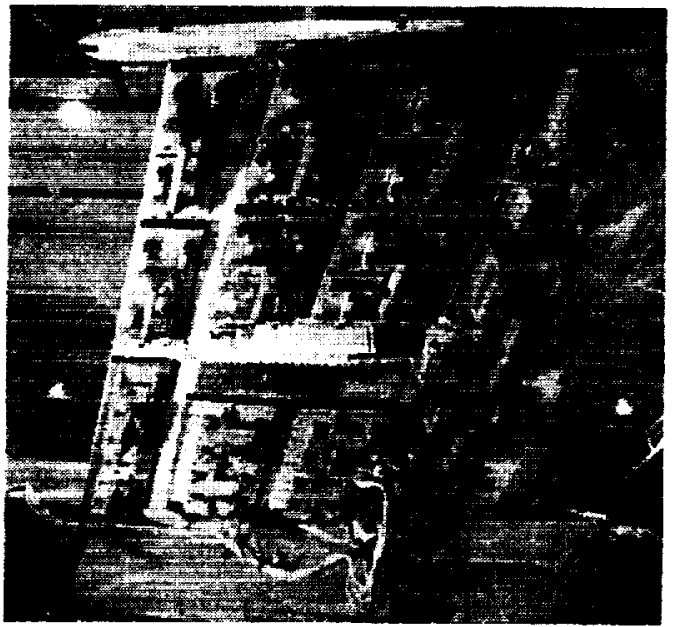

Figure 7. Load pads and whiffletrees on left wing(viewed looking up and inboard). 
During calibration testing on the airplane, one of the load pads failed in tension and separated from the wing because of a void in the bond line on the curved surface of the leading-edge outboard flap. Figure 8 shows the failed load pad. Testing was suspended for several days while the load pad was rebuilt with new rubber. During

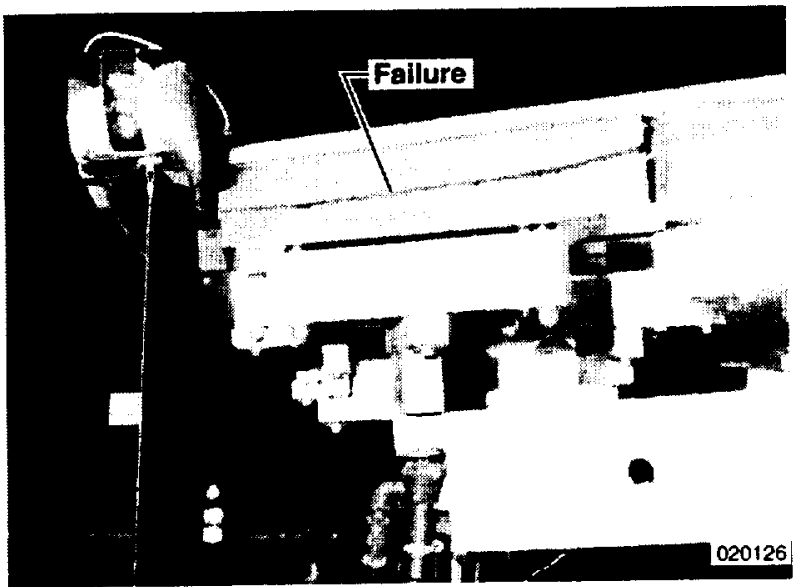

Figure 8. Failed load pad (zone 12, right).

rebonding to the wing, the load pad was supported by several specially prepared support posts nicknamed "pogo sticks." In parallel with rebuilding the failed load pad, all load pads on the leading-edge control surfaces were injected with additional sealant to prevent additional failures. Several pads readily accepted additional sealant, confirming the suspected bond voids. During subsequent testing, one load pad was found to have developed a small tear (fig. 9). This pad was repaired in place by coating the damaged area with sealant. The use of planned frequent inspections precluded a total pad failure in this case. Inspection after test completion found no damage to the AAW airplane.

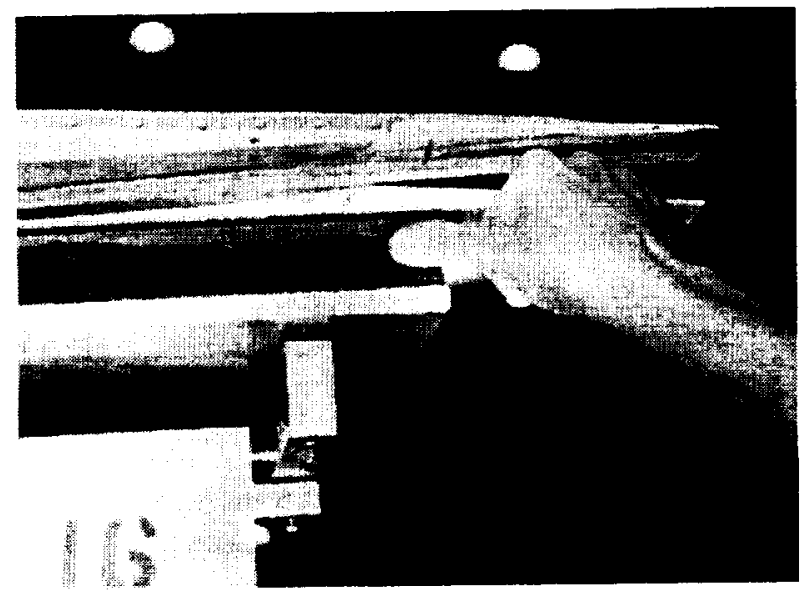

Figure 9. Torn load pad (zone 16, left).
Creep loading on the rubber was reduced by supporting the load pads with the pogo sticks while the airplane sat idle over weekends. Creep loading was a concern because the loading hardware weighed $1,065 \mathrm{lb}$ for each wing and was in place for approximately $2 \mathrm{mo}$.

\section{Whiffletrees}

The loading scheme included 52 load pads divided among 16 load zones on each wing (fig. 6). Each load zone had one jack connected to either two, three, or four load pads through whiffletrees. Figure 10 shows the part set and assembled four-pad whiffletree.

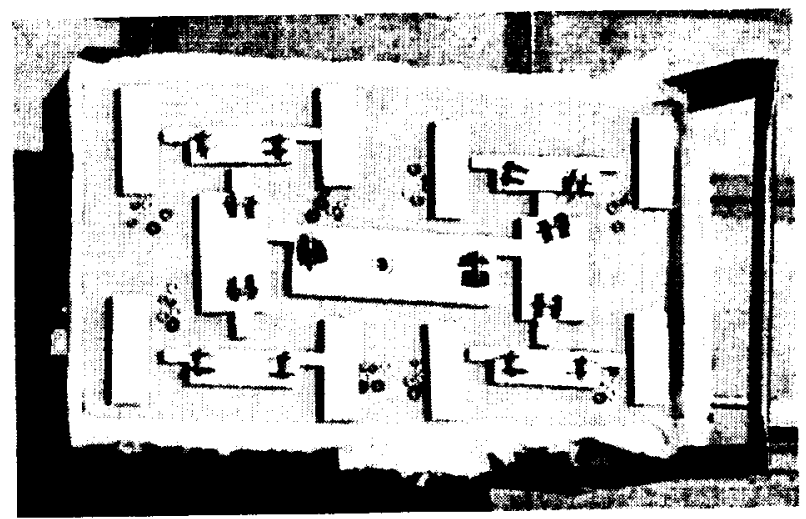

(a). Part set.

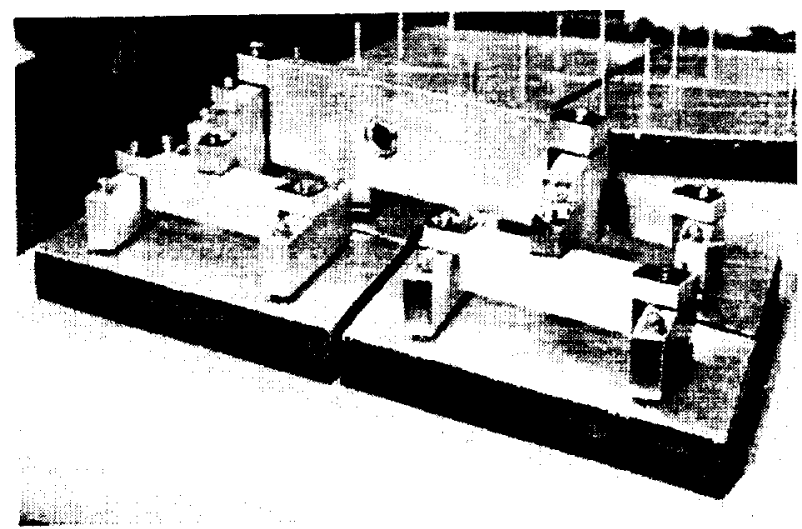

(b). Assembled.

Figure 10. Four-pad whiffletree.

The whiffletrees were designed to distribute applied load to each pad to achieve a uniform average pad pressure (larger pads receive a larger share of the zone load). Whiffletree components were designed using a factor of safety of 3.0 on ultimate for strength with adequate stiffness to preclude any undesirable deflection. The whiffletree joints were designed to accommodate enough rotation so that each pad within a 
zone could conform to the worst-case predicted elastically deformed wing shape.

As a risk reduction effort, a three-pad whiffletree set and a four-pad whiffletree set were qualificationload-tested to 110 percent of the maximum compressive zone load. Figure 11 shows the four-pad test setup. The success criteria of these tests were no component yielding, no excessive deformations, and smooth and adequate joint rotation under load. No major problems were found; however, a small deficiency in the whiffletree was revealed in the category of durability. The one-sixteenth-inch-thick cotton fiber-reinforced rubber sheet that lined metal-to-metal joints disintegrated after just a few load cycles. Before the qualification testing concluded, a polyurethane material was obtained and substituted for the rubber. During retesting, the polyurethane-lined joints performed well. These tests were not intended to prove strength but to show acceptable behavior under compressive load. The tested whiffletree sets were later used in the aircraft calibration loading.

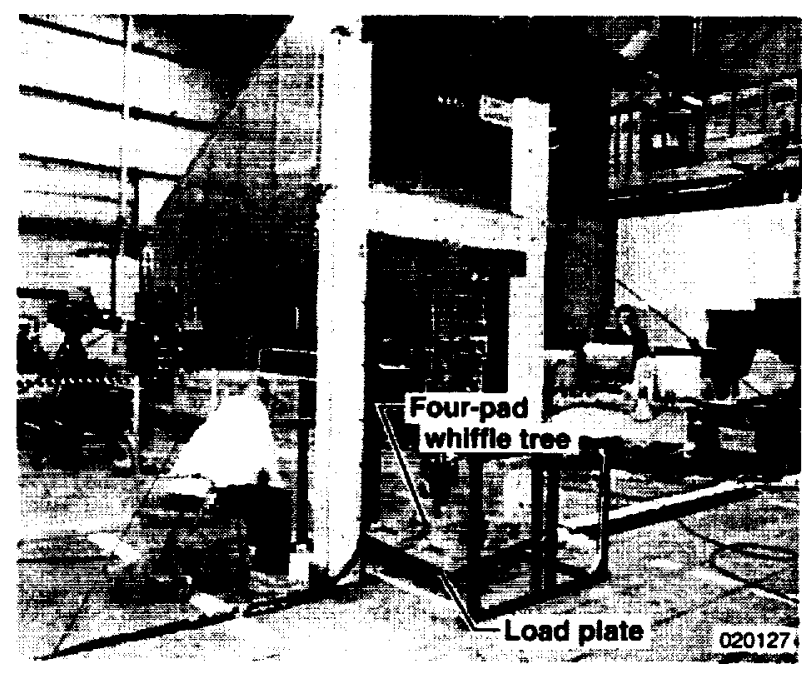

Figure 11. Whiffletree qualification test setup.

During the aircraft calibration loading, these joint liners generally worked well; with the exception that during high-tension loading, a few that were the least well-captured would deform enough to pop out of place. This exception was only a nuisance that resulted in having to periodically replace a few liners during aircraft test operations. Whiffletrees were inspected after each test run. During these inspections, special attention was given to the whiffletree bolts that underwent greater loads because they had the tendency to loosen during load. This loosening was the anticipated consequence of the decision not to use thread-locking compound on the bolts during assembly.

\section{Clevises and Load Cells}

Clevises were designed and fabricated to mate the load cells to the first beam of each whiffletree. Design criteria included the standard factor of safety of 3 on strength, with adequate space for the necessary rotation of that joint under maximum load. As the wing deflected under load, several joints could experience binding between the clevis and the whiffletree. Figure 12 shows a photograph of a clevis during the aircraft load test that illustrates the clearance problem. Clevis binding was watched for during calibration loading and was detected several times, resulting in test interruption. Although this binding was usually remedied by retorqueing the whiffletree joint bolts, removing a small amount of metal from the first whiffletree crossbeam was necessary in three locations.

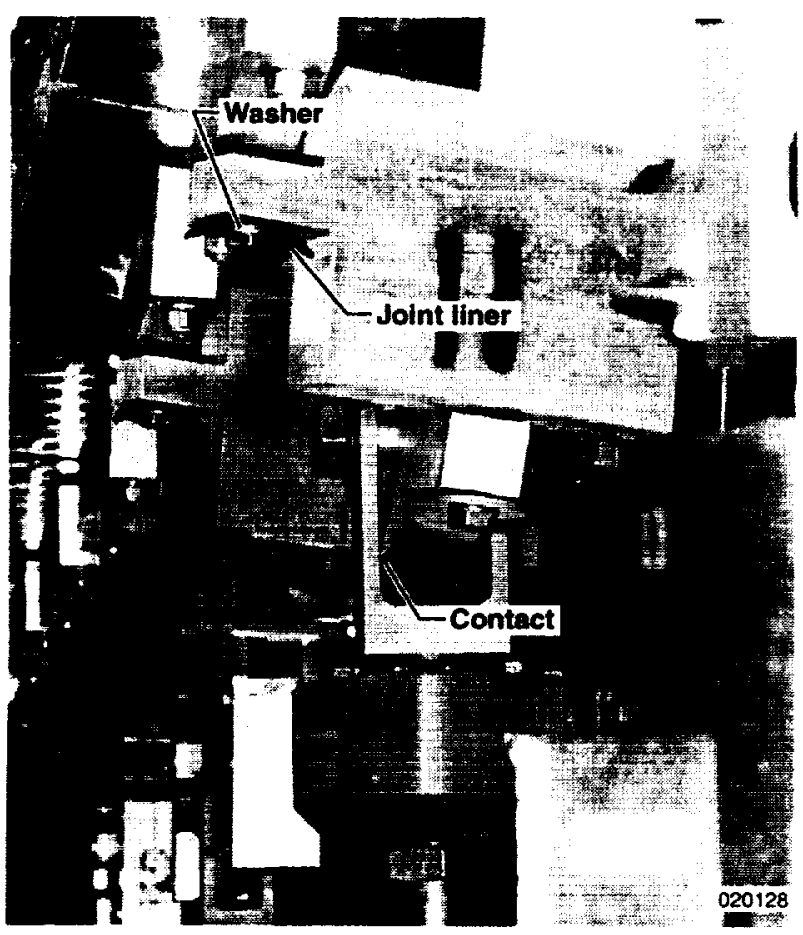

Figure 12. Clevis binding.

Dual-bridge load cells were used. One bridge provided feedback to the load controller, and the other provided test data to the DACS that were recorded. The load cell ranges were tailored to the maximum test load for each zone. Hydraulic cylinders were sized for the maximum required load and maximum total deflection for each zone. 


\section{$\underline{\text { Jack Bases and Contoured Pins }}$}

Before the loading hardware design was complete, the possibility of load column binding at the jack base was studied. The original design anticipated a pivot point at the top and bottom of each load column. The top pivot (fig. 5), between the clevis and the first beam of the whiffletree, was planned to have two-axis rotational freedom. The bottom pivot, between the hydraulic cylinder and the jack base, was planned to have single-axis rotational capability. In the load column binding study, the conclusion was made that for those load columns not close to the wing elastic axis, enough wing rotation existed under maximum load to produce an off-axis rotation at the jack base. This off-axis rotation would put bending moment through the load cells and introduce uncertainty into the applied calibration loads. Substituting a contoured pin for the cylindrical pin in the hydraulic cylinder-to-jack base pivot joint precluded this problem. Figure 13 shows this contoured pin alongside a conventional pin and a jack base.

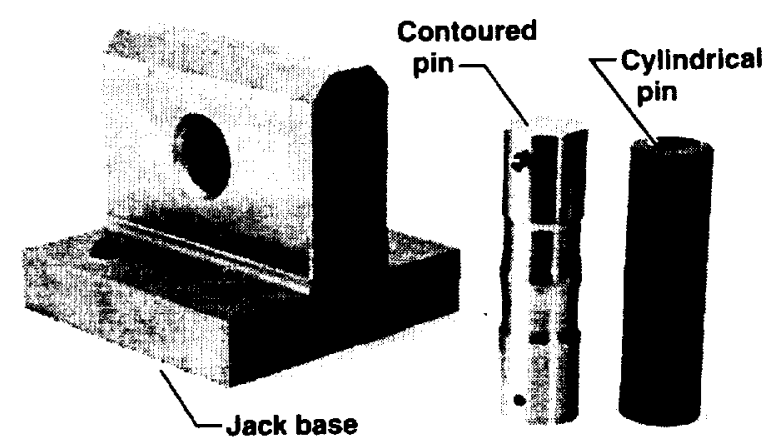

020129

Figure 13. Jack base with pins.

The contoured pin allowed as much as $4^{\circ}$ of off-axis rotation in this joint. When analyzed for stress at the worst case, conservatively showing by analysis a factor of safety of 3 for the new pin was not possible because of the significant bending moment now present. Therefore, a representative pin and jack base were proof-tested. The pin was produced from high-strength steel; the jack base was fabricated of mild steel. This test showed that the pin would not yield at two times the maximum load. Although a slight dimple was produced during this proof test in the bearing surface of the jack base, this was considered negligible. During calibration loading, no problems occurred with this design.
Because of the inevitable uncertainty in actual test geometry, height adjustability in the load column design was sought. To provide this feature, one spacer 1.25-in. thick was designed into the base of each column. Spare spacers were fabricated so that when the loading apparatus was installed, if a height problem existed, the spacer could be removed or an additional one could be added. Bolts with appropriate grip lengths were procured to accommodate spacer variability. This adjustable-height load column design proved to be successful. Several inboard load columns used short load cylinders, and therefore included jack posts as shown in figure 5 .

\section{Floor Beams}

The load column forces were reacted through the floor beams into the floor tracks. The floor beam system design (fig. 5) includes back-to-back " $\mathrm{C}$ " channels and 1.25-in.thick mild-steel plates. The platform style allowed for easy installation of the jack bases or posts. To begin the test setup, the AAW airplane was positioned in the Flight Loads Laboratory. Then the main gear restraint and arresting hook pivot support were installed, the (loose) nose gear chains were installed, the nose gear strut pressure was adjusted, and the load pads and whiffletrees were installed. Load pad installation was the most work-intensive phase of the setup series.

Next, the floor beams were bolted in place. The floor beams had been preassembled and prepositioned to save setup time. Zone load center and pad corner coordinates were quantified as they were installed through the use of a three-head theodolite system. Plumb bobs were used to transfer load center locations from the whiffletree main beam center pivots to the floor beam platforms. Plumb bobs were also used to indicate the orientation of whiffletree main beams. Using these marks and specially prepared templates, the jack base or post footprints were marked on the floor beams. The orientation of the load columns was critical to preclude binding under load. The required holes were drilled in place.

\section{Instrumentation}

Figure 14 shows the locations of the strain-gage instrumentation and primary measurement stations. Test data were provided by 200 strain-gage bridges, 54 string potentiometers, and 32 load cells. Each shear, bending, and torque bridge was a conventional four-active-arm Wheatstone bridge circuit using foil-type gages. The design of this installation follows the pattern of previous installations successfully used 


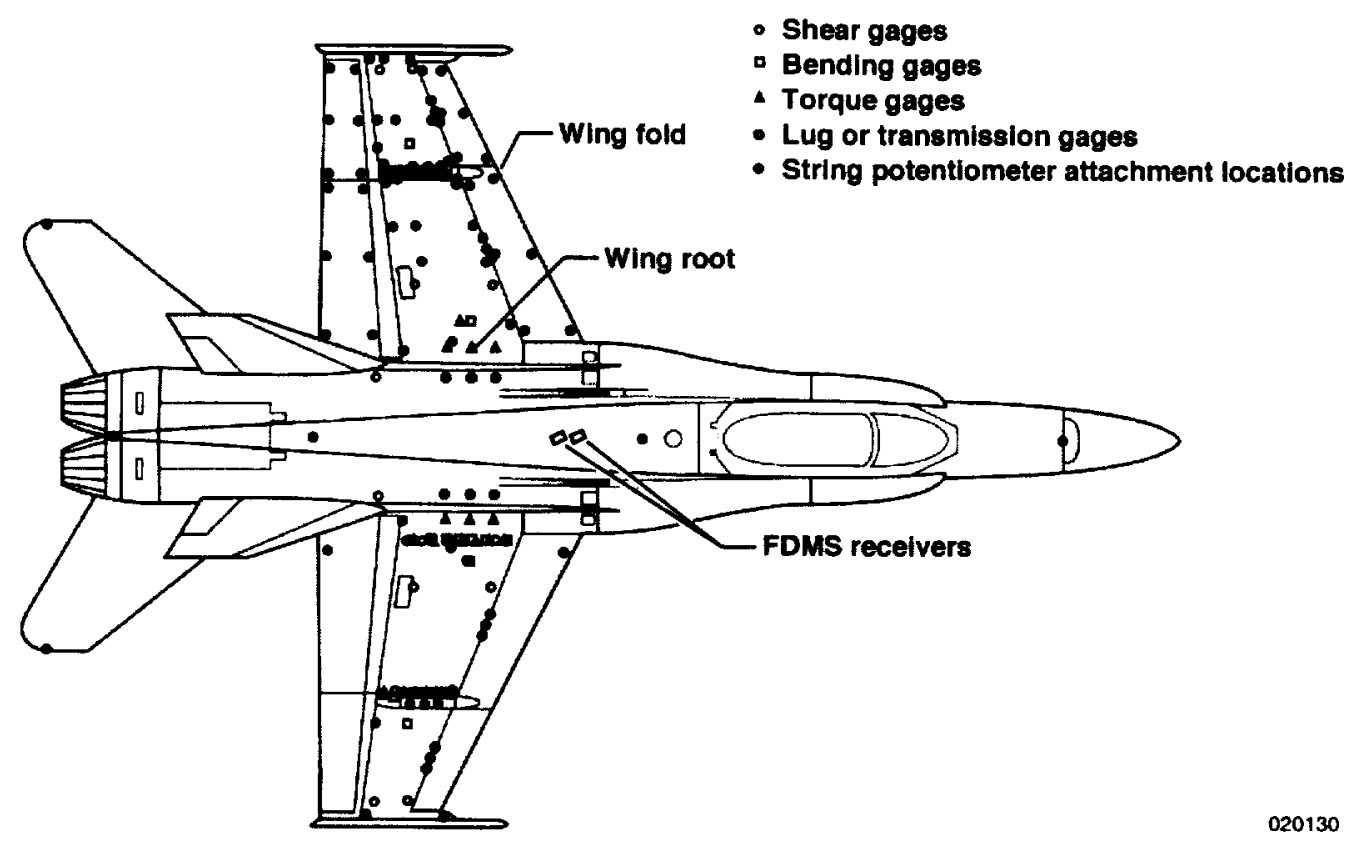

Figure 14. Instrumentation layout.

for load measurement by the aircraft manufacturer, with an additional 46 bridges for expanded research potential.

The string potentiometers (fig. 14) were used to provide test deflection measurements. Some of the overhead string potentiometers employed are visible in figure 15. The electro-optical FDMS was installed and operating for this ground test. The FDMS installation on this F/A-18 aircraft is very similar to one previously used on an F-16 aircraft. ${ }^{9}$ Sixteen of the overhead string potentiometers were colocated with the FDMS targets, which were installed on the left wing box for later data comparison. String potentiometers were also attached to the left wing control surfaces, the right wingtip, four locations on the fuselage centerline, and two locations on the main gear restraint fixtures. String potentiometer and FDMS measurement locations were documented during installation using the previously mentioned theodolite system.

\section{Data Acquisition and Control System and Displays}

Data from load cells and string potentiometers were monitored at multiple locations for safety of test. Measured loads were compared against programmed loads, and measured wingtip deflections were compared with predictions for each load case as an independent check that each test run was performing correctly. Fuselage centerline, main gear restraint fixture, and horizontal tail string potentiometers additionally were monitored for airframe rigid-body motion to verify that nothing moved that should not. Besides the monitoring of real-time data, one technician positioned at each wingtip provided direct observation of the test article and loading hardware. Closed-circuit television recorded video from two locations. This level of monitoring provided situational awareness to assure safety of test and data quality.

\section{Load Cases}

All loads were applied to the wing lower surface only. A total of 72 load cases, including single-zone, double-zone, and distributed loads were performed. During distributed loading, all 32 jacks simultaneously applied loads. The total load cases consist of 16 single-zone loads to 50 percent of the corresponding zone test limit load, 16 single-zone loads to 100 percent, 4 double-zone hinge moments to 50 percent, 24 distributed loads to 100 percent, 4 double-zone hinge moment loads to 100 percent, 2 double-zone loads on the outer wing box to 100 percent, and 4 distributed loads repeated for aircraft data system checkout. Two other load cases also were repeated. Most of the 24 cases of distributed load were designed to represent actual flight load distributions for a variety of flight conditions around the loads envelope. Twelve were defined for wing root loading, and the other 12 were defined for wing fold loading. 


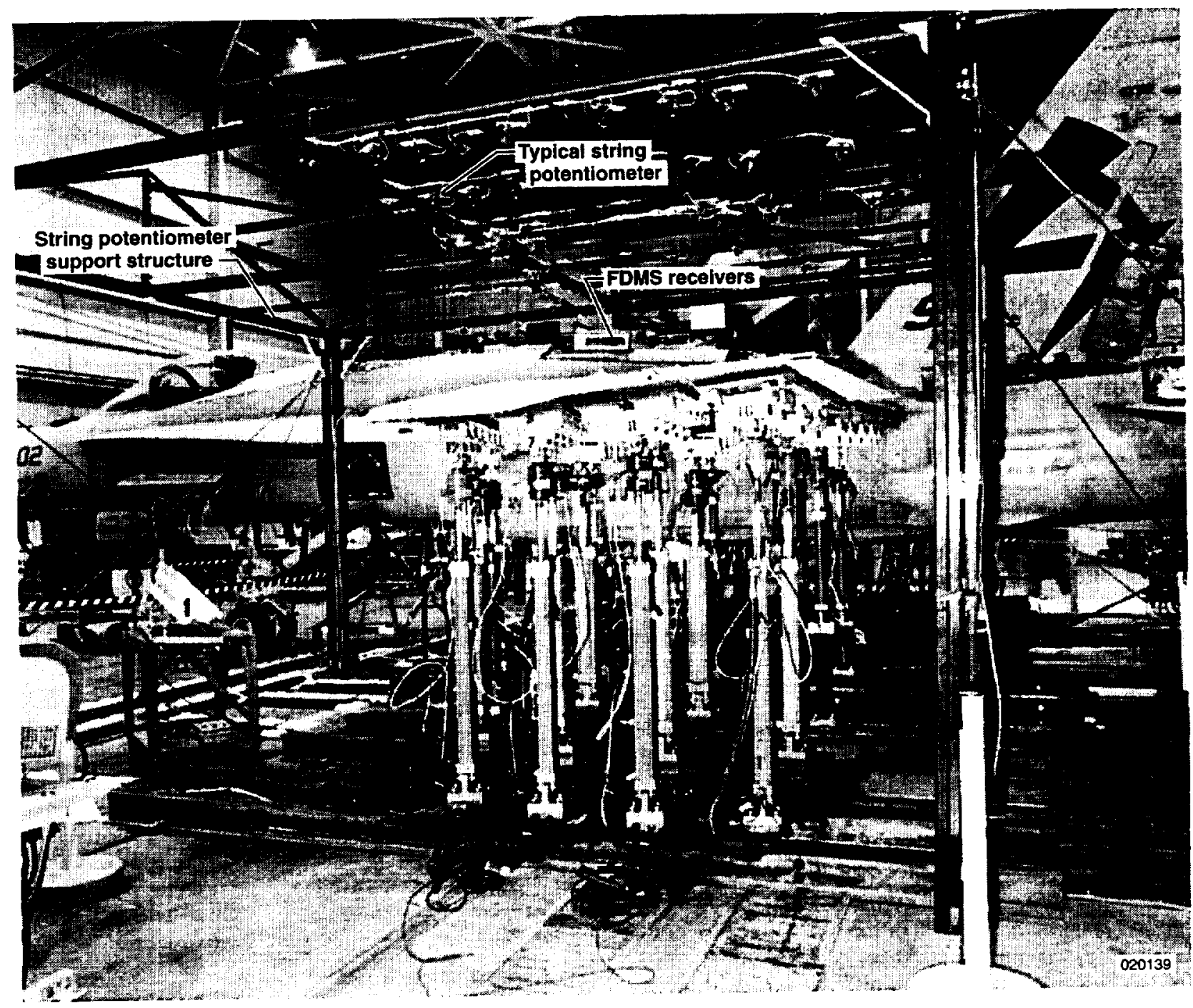

Figure 15. Left wing with string potentiometers (viewed looking inboard).

All load cases were symmetrical (left to right). Possible benefits of adding one or more antisymmetric load cases were considered; but because the wings are discrete structural units pinned to a set of massive fuselage frames (unlike the example in reference 10 , p. 141), this loading was deemed unnecessary.

\section{Analysis and Results}

A contractor-built NASTRAN finite-element stiffness model of the AAW airplane ${ }^{4}$ was used to predict the expected deflections for the wing calibration test. These predictions were used for pretest designs and real-time comparisons during testing. Before the test, the deflection predictions were used to determine whether or not sufficient up and down stroke was available for each of the jacks and if any modifications to the test setup were necessary. During the test, the deflection predictions were used as a secondary check to verify that the loads were being appropriately applied.

The process for applying the distributed loads to the model are detailed herein; the single-zone and multiple-zone loads were similarly applied. Each of the 24 cases of distributed load were applied to the finite-element stiffness model to determine expected deflections at the deflection measurement locations and at the jack locations. Because the finite-element model represents only the left half of the vehicle, the predicted deflections were used for analyses for both the left and right half. To obtain the deflection predictions, the loads had to be applied such that they would represent as accurately as possible the actual aircraft loading during 
testing. Therefore, two methods were used to apply the loads to the finite-element model.

The first method was extensively used throughout the model and more accurately represented the actual loading. This method consisted of creating 45 nodes correlating to the centers of pressure for $\mathbf{4 5}$ of the $\mathbf{5 2}$ load pads, which were attached to the left wing of the AAW airplane during calibration testing. These 45 nodes then were connected to the lower wing surface of the model using rigid-body elements at either 3 or 4 node locations. This setup allowed the applied load to be appropriately distributed to the model substructure. The 45 load application nodes were designated as the independent nodes in the rigid elements, and the wing attachment nodes were set as the dependent nodes. The deflections of the wing attachment nodes were dependent on the load application nodes in all three axes, and the rotations of these nodes were constrained about the vertical axis.

The second method was applied to the remaining seven load pads. In this method, the loads were applied to the wing skin quadrilateral elements of the model as surface pressures. These pressures were applied so that the centers of pressure on the model correlated with the center of pressure of each of the load pads.

Each distributed load configuration was evaluated to determine the expected deflections. Before the test, the expected deflections were compared with the available up and down stroke of each of the jacks. Because of this evaluation, several jack assemblies were modified before testing, which minimized the impact to the testing schedule. During testing, the predicted deflections were compared with the measured deflections to ensure that the loads were being applied as expected to the aircraft, and to evaluate the possibility of exceeding the deflection capabilities of the testing structure for future load cases. Figure 16 shows a comparison of the finite-element model-predicted deflections with the measured deflections along the forward and aft wing box measurement locations. Although the finite-element model overpredicted the deflections at the intermediate locations, the deflections at the wingtip were predicted within 2 percent of the measured deflection.

A finite-element analysis was also performed for the load pad clastomeric layer using the experimentally determined compressive stiffness curve, which was nonlinear. The analysis studied the worst-case pad pressure distribution to ensure that the peak local pressure limit of $25 \mathrm{lbf} / \mathrm{in}^{2}$ would not be exceeded. A further finite-element study was performed that modeled a bare wing with and without all load pads installed to determine how large the overall wing stiffening effect would be, which is an important consideration for producing valid load equations. The addition of the load pads was determined to have a negligible effect on wing stiffness, approximately 1 percent.

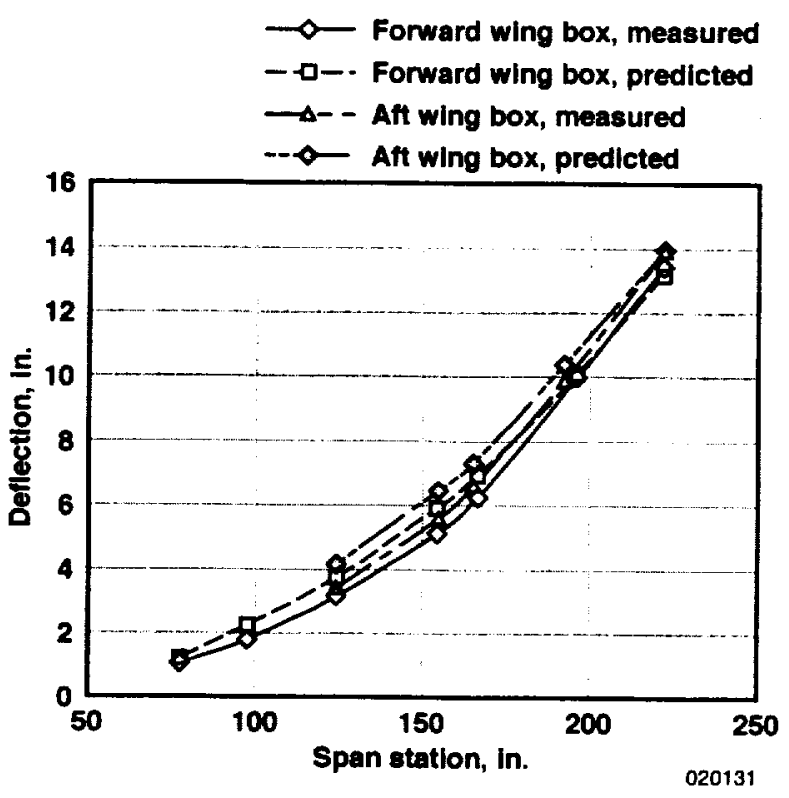

Figure 16. Comparison of predicted and measured deflections for load case D3.

Approximately $4 \mathrm{~GB}$ of data have been produced by this test series. Figure 17 shows representative strain-gage output data as a function of applied test load. The strain-gage output and load cell data for each of the 72 load cases have been plotted and reviewed for adequacy. Little noise is present in the data. Strain-gage output levels varied throughout the testing; but when examined in light of local strain levels produced, the strain gages generally produced very good output levels when significantly exercised. Strain-gage bridges proved to be generally well-located. The wing-fuselage shear tie and front and aft spar web shear strain-gage bridges yielded the largest outputs. The strain gages that had been added for research purposes also produced very good outputs. The wing lug bridges exhibited the least linear behavior of the entire database. The aileron and trailing-edge flap actuator rod end strain gages manifested bilinear trends with different slopes for tension and compression loading, which is typical of rod ends. Aside from this, the rod end strain-gage output levels were very good and the signals were quite clean. 


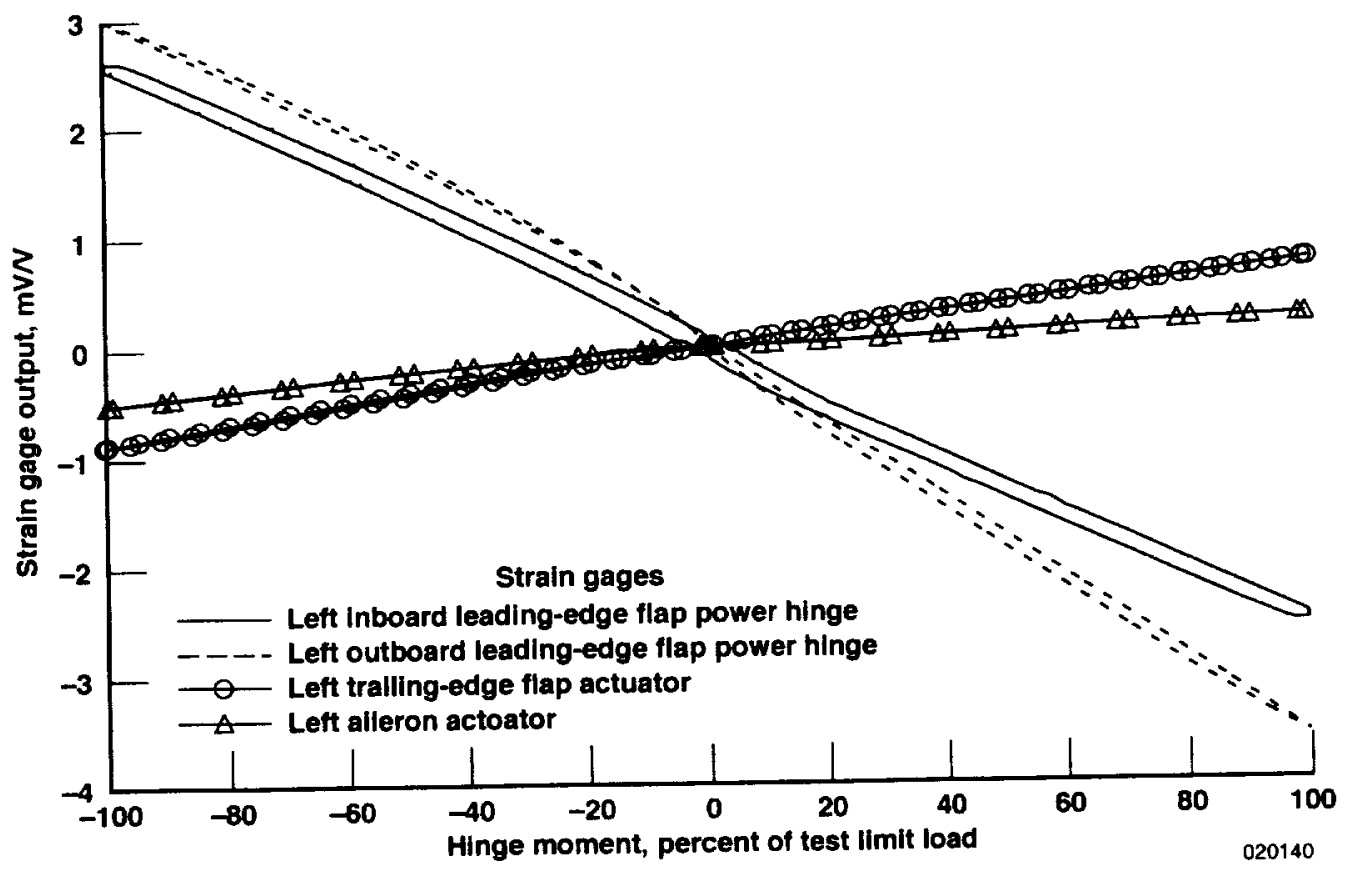

(a). Strain-gage output at control-surface hinges (acquired from dual-point hinge moment condition).

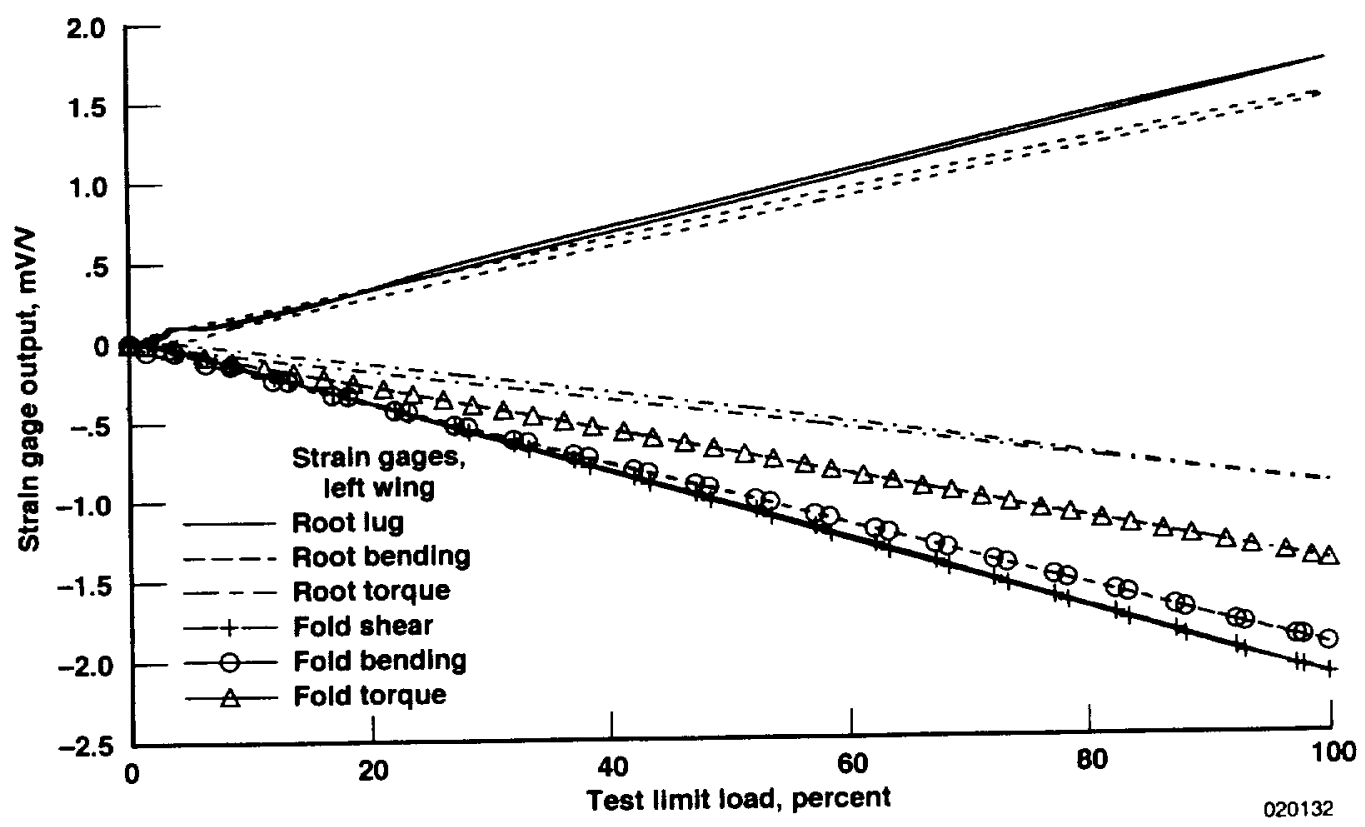

(b). Strain-gage output from wing box root and fold (acquired from distributed load cases).

Figure 17. Sample test data. 


\section{Concluding Remarks}

The primary objective of this test was to safely obtain calibration data from the strain-gage instrumentation installed on the Active Aeroelastic Wing airplane through the application of single-point, multiple-point, and distributed loads. A secondary objective was to obtain simultaneous measured data from the electrooptical flight deflection measurement system and the ground-test deflection potentiometers. Another objective was to obtain strain-gage data through both the aircraft pulse code modulation data system and the NASA Dryden Flight Research Center Flight Loads Laboratory data acquisition and control system.

All test objectives were met. A good quality calibration data base was produced safely. Initial work with this data base has produced excellent results. Simultaneous data was produced from the aircraft mounted electro-optical Flight Deflection Measurement System and the ground test string potentiometers. Strain-gage data were obtained through the aircraft pulse code modulation data system and the laboratory data acquisition and control system. Initial review of these data has provided signal to noise ratio information and confirmed good functioning of the aircraft data system.

Risk reduction load component tests and analyses were successful in precluding problems such as; load column binding, load column buckling, premature whiffletree joint liner failure, and so on. Finite-element analysis predictions of aircraft structural deflections aided test hardware design and real-time test data monitoring for safety-of-test. Available jack strokes were adequate. String potentiometer ranges likewise were satisfactory. Load pads performed well, with minimal problems. The floor beam system worked well, as did the aircraft restraint fixtures. Inspection after test completion showed no damage to the test airplane.

\section{References}

'Miller, Gerald D., "An Active Flexible Wing Multi-Disciplinary Design Optimization Method," AIAA-94-4412-CP, Sept. 1994, pp. 1388-1394.

${ }^{2}$ Pendleton, Ed, Kenneth Griffin, Michael W. Kehoe, and Boyd Perry, "A Flight Research Program for Active Aeroelastic Wing Technology," AIAA-96-1574-CP, April 1996, pp. 2263-2273.

${ }^{3}$ Pendleton, E., D. Bessette, P. Field, G. Miller, K. Griffin, "Active Aeroelastic Wing Flight Research
Program: Technical Program and Model Analytical Development," Journal of Aircraft, vol. 37, no. 4, July-Aug. 2000, pp. 554-561.

${ }^{4}$ Lokos, William A., et al., "Wing Torsional Stiffness Tests of the Active Aeroelastic Wing F/A-18 Airplane," AIAA-2002-1333, Jan. 2002.

${ }^{5}$ Skopinski, T. H., William S. Aiken, Jr., and Wilber B. Huston, Calibration of Strain-Gage Installations In Aircraft Structures For The Measurement Of Flight Loads, NACA Report 1178, 1954.

${ }^{6}$ DeAngelis, V. Michael and Robert Fodale, "Electro-Optical Flight Deflection Measurement System," SFTE Technical Paper 22, Sept. 1987.

${ }^{7}$ Dyrden Flight Research Center, "Flight Loads Laboratory," Uniform Resource Locater www.dfrc.nasa.gov/organizations/FLL/index.html,

Sept. 24, 2001.

${ }^{8}$ Crawford, Natalie D., "Load Pad Development for Research Aircraft Wing Strain Gage Loads Calibration Test," SEM Paper Number 46, to be published June 2002.

${ }^{9}$ Lokos, William A., Catherine M. Bahm, and Robert A. Heinle, "Determination of Stores Pointing Error Due to Wing Flexibility Under Flight Load," AIAA 94-2112, June 1994.

${ }^{10}$ Jenkins, Jerald $M$. and V. Michael DeAngelis, $A$ Summary of Numerous Strain-Gage Load Calibrations on Aircraft Wings and Tails in a Technology Format, NASA TM-4804, 1997.

${ }^{11}$ Olney, Candida D., Heather Hillebrandt, and Eric Y. Reichenbach, An Evaluation Technique for an F/A-18 Aircraft Loads Model Using F/A-18 Systems Research Aircraft Flight Data, NASA TM-2000-209028, 2000. 
Pubtic reporting burden for this collection of information is estimated to average 1 hour per response, including the time for reviewing instructions, searching existing data sources. gathering and maintaining the data needed. and completing and reviewing the collection of information. Send comments regarding this burden estimate or any other aspect of this collection of information. including suggestions for reducing this burden, to Washington Headquarters Services, Directorate for intormation Cperations and Reports, 1215 Jeflerson Davis Highway, Suite 1204 . Arlington, VA 22202-4302. and to the Office of Management and Budget, Paperwork Reduction Project (0704-0188). Washington. DC 20503

\begin{tabular}{|l|l|l|}
\hline 1. AGENCY USE ONLY (Leave blank) & $\begin{array}{l}\text { 2. REPORT DATE } \\
\text { June } 2002\end{array}$ & $\begin{array}{l}\text { 3. REPORT TYPE AND DATES COVERED } \\
\text { Technical Memorandum }\end{array}$ \\
\hline
\end{tabular}
F/A-18 Aircraft.

6. AUTHOR(S)

7063500 E8 $1400 \mathrm{AAW}$

William A. Lokos, Candida D. Olney, Tony Chen, Natalie D. Crawford, Rick Stauf, and Eric Reichenbach

7. PERFORMING ORGANIZATION NAME(S) AND ADDRESS(ES)

NASA Dryden Flight Research Center

P.O. Box 273

Edwards, California 93523-0273

H-2490

9. SPONSORINGMONITORING AGENCY NAME(S) AND ADDRESS(ES)

10. SPONSORINGMONITORING

AGENCY REPOAT NUMBER

National Aeronautics and Space Administration

Washington, DC 20546-0001

NASA/TM-2002-210726

\section{SUPPLEMENTARY NOTES}

Also presented at the 22nd AIAA Aerodynamic Measurement Technology and Ground Testing Conference, St. Louis, Missouri June 24-27, 2002.

12a. DISTRIBUTIONAVAILABILITY STATEMENT

12b. DISTRIBUTION CODE

Unclassified-Unlimited

Subject Category 05

This report is available at http://www.dfrc.nasa.gov/DTRS/

13. ABSTRACT (Maximum 200 words)

This report describes strain-gage calibration loading through the application of know'n loads of the Active Aeroelastic Wing F/A-18 airplane. The primary goal of this test is to produce a database suitable for deriving load equations for left and right wing root and fold shear; bending moment; torque; and all eight wing control-surface hinge moments. A secondary goal is to produce a database of wing deflections measured by string potentiometers and the onboard flight deflection measurement system. Another goal is to produce strain-gage data through both the laboratory data acquisition system and the onboard aircraft data system as a check of the aircraft system. Thirty-two hydraulic jacks have applied loads through whiffletrees to 104 tension-compression load pads bonded to the lower wing surfaces. The load pads covered approximately 60 percent of the lower wing surface. A series of 72 load cases has been performed, including single-point, double-point, and distributed load cases. Applied loads have reached 70 percent of the flight limit load. Maximum wingtip deflection has reached nearly 16 in.

\begin{tabular}{|c|c|c|c|}
\hline \multirow{2}{*}{\multicolumn{3}{|c|}{$\begin{array}{l}\text { 14. SUBJECT TERMS } \\
\text { Strain gage calibration, loads testing, load equations, load measurement, load } \\
\text { calibration }\end{array}$}} & \multirow{2}{*}{$\begin{array}{l}\text { 15. NUMBER OF PAGES } \\
15 \\
\begin{array}{l}\text { 16. PAICE CODE } \\
\text { A03 }\end{array}\end{array}$} \\
\hline & & & \\
\hline $\begin{array}{l}\text { 17. SECURITY CLASSIFICATION } \\
\text { OF REPORT } \\
\text { Unclassified }\end{array}$ & $\begin{array}{l}\text { 18. SECURTRY CLASSIFICATION } \\
\text { OF THIS PAGE } \\
\text { Unclassified }\end{array}$ & $\begin{array}{l}\text { 19. SECURITY CLASSIFICATION } \\
\text { OF ABSTRACT } \\
\text { Unclassified }\end{array}$ & $\begin{array}{l}\text { 20. LIMTAATION OF ABSTRACT } \\
\text { Unlimited }\end{array}$ \\
\hline
\end{tabular}

